\title{
Clinical results and complications of preventive laparoscopic assisted gastropexy in 17 dogs: preliminary study
}

\author{
Lucie Urbanová, Michal Crha, Petr Raušer, Alois Nečas \\ Department of Surgery and Orthopaedics, Small Animal Clinic, Faculty of Veterinary Medicine, \\ University of Veterinary and Pharmaceutical Sciences Brno, Czech Republic
}

Received January 18, 2010

Accepted June 15, 2010

\begin{abstract}
In terms of GDV prevention, a number of non-surgical measures are recommended. However, the only truly reliable method is gastropexy, most often as part of a surgical treatment of GDV. Gastropexy may be performed preventively either during laparotomy indicated for another reason than GDV, or newly laparoscopically, as independent preventive gastropexy.

Preventive laparoscopic assisted gastropexy (PLAG) was performed in 17 patients at the Department of Surgery and Orthopaedics of the Small Animal Clinic at the University of Veterinary and Pharmaceutical Sciences in Brno. Clinical results and complications of PLAG were evaluated 3-12 months after surgery.

The most frequent clinical finding of PLAG was a skinfold at the site of gastropexy immediately after the surgery $(n=8 ; 47 \%)$, or still on day 12 after the surgery $(n=1 ; 6 \%)$. As for PLAG complications, in one case a seroma formation was found at the site of gastropexy $(6 \%)$; in two patients iatrogenic perforation of the splenic capsule $(12 \%)$ occurred, which in one case gave reason to converting laparoscopy into laparotomy $(6 \%)$. In none of the patients, death, gastropexy failure, GDV development, dehiscence, infection of or haemorrhage from the surgical wound were noted.

Laparoscopic assisted gastropexy appears as a reliable and miniinvasive surgical method of GDV prevention and it may be recommended for high-risk breeds of dogs.
\end{abstract}

Gastric dilatation-volvulus, stomach, miniinvasive surgery, GDV, prophylaxis

Gastric dilatation-volvulus (GDV) is a life threatening disease and its mortality ranges from 10 to $60 \%$ (Arons on et al. 2000). GDV is the second most frequently stated cause of death in large breeds of dogs (Glickman et al. 1994, 2000). Precise causes and principles of the origin of the disease are still unknown; only risk factors have been identified, such as decreased stomach motility and its lengthened emptying (Greenfield et al. 1989; Hall et al. 1989; Hall 1989). In terms of "external" factors, the origin of the disease is affected by the diet, amount of feed received, manner of receiving feed, and stress (Funkquist 1979; Burrows et al. 1985; Glickman et al. 1997; Theyse et al. 1998).

The most threatened by GDV are dogs of large and giant breeds, deep-chested dogs, and old and overweight individuals (Schaible et al. 1997; Glickman et al. 2000a; Glickman et al. 2000b). Specifically speaking, GDV occurs most frequently in the Great Dane, Weimaraner Pointer, German Shepherd, Saint Bernard dog, Gordon and Irish Setter (Glickman et al. 1994). It has been stated that dogs with a "happy" temperament are at a lower risk of GDV occurrence (Glickman et al. 1997). Another factor that markedly increases the risk of this disease is previous splenectomy (Millis et al. 1995).

Preventive non-surgical measure recommendations for the prevention of gastric dilatation include resting before and after feeding, "checking up" the dog's condition 2-4 h after feeding, dividing the daily feeding dose into 2-3 servings per day, selecting the optimal size of food granules etc. A large number of studies dealing with factors affecting the origin and development of GDV have been conducted (Van Kruiningen et al. 1974; Kronfeld 1979; Morgan 1982; Glickman et al. 1994, 1996, 1997, 2000; Elwood 1998) but gastric

Address for correspondence:

MVDr. Lucie Urbanová

Department of Surgery and Orthopaedics

Small Animal Clinic, Faculty of Veterinary Medicine

University of Veterinary and Pharmaceutical Sciences Brno

Palackeho 1-3, 61242 Brno, Czech Republic

Phone: +420 541562349

E-mail: lucieurbanova@email.cz

http://www.vfu.cz/acta-vet/actavet.htm 
volvulus can be prevented demonstrably only by gastropexy (Rawlings 2000). It is also the only broadly recognized method of GDV prevention (Rawlings 2000; Monnet 2003), most often as part of a proper surgical treatment of the GDV syndrome. If during the treatment of the GDV syndrome gastropexy is not performed, the risk of recurrence is around 80\% (Wingfield et al. 1975; Eggertsdottir and Moe 1995; Glickman et al. 1998). A number of gastropexy methods have been described including incisional gastropexy, tube gastropexy, circumcostal gastropexy, belt-loop gastropexy, or possibly gastrocolopexy (Fossum 2007). The mentioned methods of stomach fixation differ in their strength and difficulty in performing but all of them are reliable enough (Monnet 2003).

At our department, we advice preventive gastropexy to clients of predisposed dog breeds in cases when laparotomy is indicated for other reasons (e.g. ovariohysterectomy, procedures on the gastrointestinal or urinary tracts), and most frequently we perform incisional gastropexy.

Preventive gastropexy should decidedly be advised for patients that have already been treated for a gastric disease accompanied with gastric tympany (Rawlings 2002).

Gastric dilatation-volvulus syndrome is a disease relatively frequently occurring in practice (Glickman et al. 1994). At our department, we surgically treat around 70 cases of GDV a year. Typically, this disease has a peracute course, requiring a prompt surgical solution mostly during the night time. In the course of treatment a number of complications may occur and the GDV treatment is expensive for the owners, and therefore they sometimes require euthanasia instead of treatment. Although it is generally known that predisposition to this disease is genetically conditioned (Glickman et al. 2000), breeding clubs do not monitor this fact in any way and do not adjust to it even in the breeding of the predisposed dog breeds. Moreover, clients tend to refuse the mentioned invasive methods of gastropexy associated with a laparotomic approach as prevention of GDV, unless it is accompanied with another indication for laparotomy. Considering the above mentioned factors, in connection with introducing new miniinvasive laparoscopic techniques in small animal surgery at our department we started to perform preventive laparoscopic assisted gastropexies, either independently or in combination with ovariectomy/ovariohysterectomy. By introducing laparoscopic assisted gastropexy into common practice at the Department of Surgery and Orthopaedics of the Small Animal Clinic at the University of Veterinary and Pharmaceutical Sciences in Brno (Crha et al. 2007); new possibility has opened for reliable GDV prevention with all the advantages of a miniinvasive surgical procedure. In this article we present our experience and primary results regarding miniinvasive laparoscopic assisted gastropexy in clinical patients.

\section{Materials and Methods}

At the Department of Surgery and Orthopaedics of the Small Animal Clinic at the University of Veterinary and Phramaceutical Sciences in Brno, preventive laparoscopic assisted gastropexy was performed from January 2009 until September 2009 (once in combination with laparoscopic ovariectomy) in a total of 17 patients (12 males and 5 females) at the age of 9 months to 9 years and body weight of $45.8 \pm 10.4 \mathrm{~kg}$. The dogs were of breeds predisposed to this disease, namely 4 Great Danes, 3 Labrador Retrievers, 2 Rottweilers, 1 White Swiss Shepherd, 1 Scottish Deerhound, 1 Newfoundland Dog, 1 Dogue de Bordeaux, 1 Rhodesian Ridgeback, 1 Cane Corso, 1 German Shepherd and 1 Golden Retriever. Most patients underwent anaesthesia (or another surgical procedure) for another reason, e.g. radiological diagnostics of a developmental joint disease, tumour excision, follow-up examination after previous orthopaedic surgery, arthroscopic joint surgery, or preventive ovariectomy (also performed laparoscopically). The owners were offered the possibility of preventive gastropexy using laparoscopic assisted method during the primary examination of the patient.

Upon premedication with medetomidine $(0.01 \mathrm{mg} / \mathrm{kg}$ i.v., Domitor, Orion Corp. $)$ and butorphanol $(0.2 \mathrm{mg} / \mathrm{kg}$ i.m., Butomidor, Richter Pharm.), the patients were introduced to general anaesthesia using propophol (1-2 mg/ $\mathrm{kg}$ i.v., Propofol, Fresenius Kabi); anaesthesia was further conducted by inhalation using a mixture of oxygen, air (at a ratio of $1: 1)$ and isoflurane $(1-1.5 \%$, Forane, Aesica Ltd.). 
During anaesthesia, they were monitored for ECG, arterial blood pressure (invasively through a. metatarsalis dorsalis), saturation of haemoglobin by oxygen $\left(\mathrm{SpO}_{2}\right)$ and endexpiration concentration of $\mathrm{CO}_{2}\left(\mathrm{ETCO}_{2}\right)$. During the whole anaesthesia (including the capnoperitoneum time), the patients were kept on artificial ventilation, maintaining the $\mathrm{ETCO}_{2}$ level within the range of $30-40 \mathrm{~mm} \mathrm{Hg}$. During introduction to anaesthesia, antibiotics were administered at a single dose according to the principle of "protected coagulum" (amoxycilin-clavulanate $20 \mathrm{mg} / \mathrm{kg}$ i.v. - Augmentin $600 \mathrm{mg}$, Smith Kline Beecham Pharm.). Amoxycilin-clavulanate $20 \mathrm{mg} / \mathrm{kg}$ i.m. (Synulox, Haupt Pharma) and meloxicam $0.2 \mathrm{mg} / \mathrm{kg}$ s.c. (Metacam, Boeringer Ingelheim Pharm.) were applied postoperatively.

After the insertion of a Verres needle into the abdominal cavity paramedially to the right behind the last rib, capnoperitoneum was formed by $\mathrm{CO}_{2}$ insufflation. Upon obtaining capnoperitoneum of a pressure within the range of 10-12 $\mathrm{mm} \mathrm{Hg}$, a video camera portal was established by puncture incision in the umbilical region for a rigid telescope (Smith \& Nephew, US) of the diameter of $5 \mathrm{~mm}$ with the optical lens angle of $30^{\circ}$. Routine laparoscopic revision of the organs of the abdominal cavity was performed and then the stomach and its position were examined. After examination of the stomach position, or after making it accessible by pulling away the fat and the omentum, an optimal site was localized in the abdominal wall for performing gastropexy (Plate IV, Fig. 1) and at this site (laterally to the right from the border of $\mathrm{m}$. rectus abdominis and approximately $3 \mathrm{~cm}$ behind the last rib) a second (instrument) portal was established under optical control. For establishment of portals (both optical and instrumental) cannulas of the diameter of $5 \mathrm{~mm}$ with safety trockars were used (Ethicon ${ }^{\circledR}$, Johnson\&Johnson comp., US). Using inserted atraumatic forceps (Smith\&Nephew, US), the stomach was grasped through the work portal in its prepyloric part between the greater and lesser curvature (outside the blood vessels) and slightly pulled closer to the abdominal cavity wall.

Approximation of the stomach to the abdominal wall facilitated cancellation of capnoperitoneum by releasing $\mathrm{CO}_{2}$ through the instrument portal. Parallel to the last rib, through an incision enlarged to approximately $2-3 \mathrm{~cm}$ for the instrument portal, the grasped part of the stomach was exteriorized through the abdominal wall and fixated externally using fixation sutures (Plate IV, Fig. 2). Then the seromuscular layer of the stomach was incised in the extent of approximately $3 \mathrm{~cm}$ and the seromuscular flap was created. The seromuscular flap was sutured using continuous pattern with synthetic nonabsorbable monofilament suture material (Prolene 2-0, Ethicon ${ }^{\circledR}$ ) to the peritoneum and musculus transversus abdominis. The subsequent suture using synthetic absorbable monofilament suture material (PDS 2-0, Ethicon ${ }^{\circledR}$ ) included m. obliqus abdominis internus and $\mathrm{m}$. obliqus abdominis externus. Subcutaneous layer was sutured using two different methods with synthetic absorbable monofilament suture material (PDS 2-0, Ethicon ${ }^{\circledR}$ ). In some patients, subcutaneous layer was sutured precisely without leaving a "dead" space $(\mathrm{n}=11)$, in some patients hypodermis was closed by approximating only relevant layers one to another without including deeper layers of tissue into this suture $(n=6)$. The skin in the area of gastropexy was sutured using simple interrupted sutures with synthetic nonabsorbable suture material (Ethilon 3-0, Ethicon ${ }^{\circledR}$ ).

In conclusion of the surgical procedure, visual laparoscopic revision of gastropexy was performed (Plate V, Fig. 3) with an orientation check up of its breaking strength by repeated $\mathrm{CO}$ insufflation up to the pressure of $8 \mathrm{~mm}$ $\mathrm{Hg}$. Subsequently the video camera portal was removed and the stab incision of the abdominal wall was closed at the site of the original portal using simple interrupted suture with synthetic absorbable monofilament suture material (PDS 2-0, Ethicon ${ }^{\circledR}$ ), the skin was closed using simple interrupted suture with synthetic nonabsorbable suture material (Ethilon 3-0, Ethicon $^{\circledR}$ ).

Postoperative analgesia was achieved by a single application of carprofen (Rimadyl ${ }^{\circledR}$, Pfizer) at the dose of $3 \mathrm{mg} / \mathrm{kg}$ s.c.

In patients with preventive laparoscopic assisted gastropexy (PLAG), clinical findings and complications were evaluated in the course of 3-12 months following surgery.

\section{Results}

In terms of clinical findings related to preventive laparoscopic assisted gastropexy in our patients, we found the occurrence of a skinfold in the region of gastropexy (Plate $\mathrm{V}$, Fig. 4) immediately after the surgery $(\mathrm{n}=8 ; 47 \%)$, or still at the time of skin suture extraction, i.e. on day 12 after surgery $(n=1 ; 6 \%)$. As a less serious complication of the surgical procedure related to preventive laparoscopic assisted gastropexy a seroma was found in one dog at the place of gastropexy $(6 \%)$. Two clinical findings were also found directly unrelated to the performance of PLAG. In two dogs, (1 Rottweiler, 1 Rhodesian Ridgeback), a ligament strip was found by chance, extending across the body of the stomach toward porta hepatis, causing its slight constriction. This ligament was interrupted in both cases using the LigaSure ${ }^{\circledR} 5 \mathrm{~mm}$ instrument (Valleylab, Tyco Healthcare UK) (Plate VI, Fig. 5). In two dogs, (1 Rottweiler, 1 Labrador Retriever) examination of the stomach was complicated by its enclosure in the omentum (encircling by the omentum) or by its covering by the fat tissue of ligamentum falciforme. 
With regard to possible serious complications related to preventive laparoscopic assisted gastropexy, in none of the 17 operated dogs death, failure of gastropexy or development of gastric dilatation-volvulus syndrome were noted in the monitored period (3-12 months after surgery). We also did not find complications such as surgical wound dehiscence, surgical wound infection or surgical wound haemorrhage in this group of patients.

In two dogs $(12 \%)$, iatrogenic perforation of the splenic capsule occurred (Plate VI, Fig. 6); in one of these dogs, due to the damage to the spleen we converted laparoscopic procedure to laparotomy $(6 \%)$

\section{Discussion}

Clinical findings and possible complications related to laparoscopic assisted gastropexy that were noted in our group of dogs may be divided according to seriousness into two groups: less serious complications (not life-threatening and not markedly complicating the wound healing process), and the serious ones

The clinical finding of a skinfold at the site of gastropexy can be considered only as a cosmetic blemish that appeared in $8 \mathrm{dogs}$ as a result of suturing the subcutaneous layer to the superficial fascia of the abdominal wall, preventing the free movement of the skin on deeper layers of the abdominal wall. This skinfold was accentuated in the early postoperative period by oedema and contraction of the abdominal muscles caused by local pain at the site of incision of the abdominal wall muscles. In 7 out of 8 dogs, the skinfold disappeared spontaneously within 12 days and in its original place only slight fibrous reaction could be palpated. Seroma at the site of gastropexy occurred only in one dog (in the Cane Corso breed) and was solved by a single puncture at the time of skin suture extraction (12 days after the surgery). "Accurate" suturing of hypodermis without leaving a "dead" space leads to the creation of an esthetically unsatisfactory skinfold, whereas looser suturing of hypodermis (approximation of relevant abdominal wall layers to each other without suturing deeper layers) lead in one case to seroma formation.

Although the above mentioned skinfold is only temporary cosmetic problem after the surgery, we are at present developing methodology of laparoscopic assisted gastropexy at our department that would be able to prevent it. The occurrence of haematoma must be presumed with each tissue incision and possible imperfect haemostasis during surgery. In our study we did not find a haematoma complicating PLAG healing, perhaps due to the miniinvasive technique of the surgical procedure.

The covering of the stomach by the omentum and fat tissue ranks among the less serious findings, however, they do make the procedure harder to perform for the surgeon, and it is necessary to take these findings into account in an operation. This was found in 2 patients and in both cases we were able to relatively easily remove the omentum from the stomach in caudal direction using atraumatic forceps without damaging the omentum or the gastric wall. It is necessary to take into account larger amounts of fat tissue deposits in the abdominal cavity mainly in obese individuals, where the performance of laparoscopic assisted procedure may be in general technically more difficult.

In one Rottweiler and one Rhodesian Ridgeback in our group of patients a ligament strip stretched across the body of the stomach toward the liver. From previous experience gained during operations of GDV when we encountered a similar phenomenon in several cases, we assume that this ligament structure may be one of the causes contributing to the origin and development of GDV. In both cases the strip was interrupted without difficulties using the LigaSure ${ }^{\circledR}$ instrument (Valleylab, Tyco Healthcare UK) with the ending of a $5 \mathrm{~mm}$ diameter.

Among serious complications we included findings that could directly threaten the patient's life or worsen or prevent the healing of the surgical wound. Thanks to maintaining 
the principles of asepsis during the surgical procedure, using high quality surgical instruments and suture materials and the correct PLAG technique (Thomps on et al. 1992; Wilson et al 1996; Hardie et al. 1996; Rawlings 2002), no dehiscence, infection of or bleeding from the surgical wound occurred in any of the cases.

The iatrogenic perforation of the splenic capsule, which occurred in two of our patients during insertion of the optical portal or the Verres needle, is one of the few complications described in connection with a laparoscopic assisted procedure (McCarthy 2005).

In the first case, the wound to the spleen was caused by a damaged spring mechanism of the safety trocar. Laceration of the capsule and parenchyma of the spleen in this case lead to more intense haemorrhage, therefore we were forced to convert into laparotomy and we performed splenectomy and incisional gastropexy. In the second case the splenic capsule was perforated by the Verres needle during induction of capnoperitoneum. Haemorrhage from the spleen in this case was only moderate. Stab incision of the splenic capsule was approximately $1.5 \mathrm{~mm}$ large and therefore we continued with the laparoscopic assisted technique of gastropexy. Haemorrhage from the spleen after its puncture by the Verres needle ceases by itself in individuals with undisturbed haemoregulatory activity, and in our experience, even temporary careful compression of the site of puncture suffices, e.g. using the closed jaw of atraumatic forceps. In this second case of iatrogenically caused haemorrhage from the spleen in relation to PLAG, haemorrhage had already been stopped during the final revision of the abdominal cavity organs and there was only minimal amount of blood in the abdominal cavity.

Possible complications of PLAG include failure of gastropexy and subsequent occurrence of GDV. We did not find this complication in our group of operated patients during 3 to 12 months after surgery.

Laparoscopic assisted gastropexy is a surgical method of GDV prevention providing all the advantages associated with minimal invasiveness of a procedure, such as: smaller surgical wound accompanied with lesser pain and a smaller scar, lower risk of blood loss resulting from surgical wound bleeding, shorter hospitalization time, faster recovery etc. (Rothuizen 1985). A great advantage of the laparoscopic approach is the possibility of revising most abdominal cavity organs without the necessity of enlarging the incision as in classical laparotomy, and concurrently, the possibility of taking biopsy in a pathological finding or its final solution (e.g. the above mentioned finding of ligament structure constricting the stomach).

Even after performing gastropexy, GDV recurs in 4-6\% of cases (Glickman et al. 1998). In our study, we did not find suture failure or GDV occurrence in any case of the operated patients. However, a more complex assessment of this possible complication requires longer-term monitoring.

Likewise, we did not find the occurrence of kidney failure related to the operation or death during or after the procedure.

Patients included in our study were within the age range of 9 months to 9 years. Such large range is due to the relatively recent introduction of laparoscopic assisted gastropexy at our department and by the fact that the owners only just start to learn about the availability and advantages of this treatment. Although the optimal time for performing preventive gastropexy is said to be 6-8 months of age (Monnet 2003), PLAG can be recommended in the predisposed breeds of dogs at any age.

The results found in connection with the PLAG technique in our first 17 clinical patients monitored for 3-12 months after surgery may be considered very promising. The operated patients continue to be monitored and the group of dogs with PLAG at our department is increasing. At the same time, if another laparoscopy/another procedure is indicated in these operated patients and the owners consent, we plan a possible second-look laparoscopy to check the condition of gastropexy (visually or by palpation-probe). 
Based on the results of this primary clinical study we may state that after routine mastering of the technique of laparoscopy, laparoscopic assisted gastropexy appears as a reliable and relatively quick surgical method of preventing the gastric dilatation-volvulus syndrome in dogs that is less invasive for the patient. PLAG may be performed in connection with another examination/treatment of the animal in anaesthesia (e.g. X-ray examination for diagnostics of hereditary developmental joint defects, elision of skin tumour etc.) With optimal equipment of the work place, appropriate experience of the surgeon and securing reliable anaesthesia, the risk of serious complications related to preventive laparoscopic assisted gastropexy may be considered minimal. In our opinion, laparoscopic assisted gastropexy can be recommended for broader inclusion in small animal practice as an appropriate and miniinvasive method of surgical prevention of the occurrence of the GDV syndrome in high-risk breeds of dogs.

\section{Klinické výsledky a komplikace preventivní laparoskopicky asistované gastropexe u 17 psů: prvotní studie}

Z hlediska prevence GDV se doporučuje řada nechirurgických opatření, avšak skutečně spolehlivou metodou je gastropexe, nejčastěji jako součást chirurgického řešení GDV. Preventivně lze gastropexi provést bud' při laparotomii indikované z jiného důvodu než GDV, nebo nově laparoskopicky jako samostatnou preventivní gastropexi.

Na Oddělení chirurgie a ortopedie, Kliniky chorob psů a koček, Fakulty veterinárního lékařství VFU Brno byla provedena preventivní laparoskopicky asistovaná gastropexe (PLAG) u 17 psů. Byly zhodnoceny klinické výsledky a komplikace PLAG za 3-12 měsíců po operaci.

Nejčastějším průvodním klinickým nálezem PLAG byla kožní řasa v místě gastropexe bezprostředně po operaci $(n=8 ; 47 \%)$, respektive ještě 12 . den po operaci $(n=1 ; 6 \%)$. Z komplikací PLAG byl v jednom př́padě zjištěn serom v místě gastropexe $(6 \%)$, u dvou pacientů došlo k iatrogenní perforaci pouzdra sleziny (12\%), což bylo v jednom př́ípadě důvodem ke konverzi laparoskopie $\mathrm{v}$ laparotomii (6 \%). U žádného $\mathrm{z}$ pacientů nedošlo k úhynu, selhání gastropexe a rozvoji GDV, dehiscenci, infekci či ke krvácení $\mathrm{z}$ operačních ran.

Laparoskopicky asistovaná gastropexe se jeví jako spolehlivá a miniinvazivní chirurgická metoda prevence GDV a lze ji doporučit zvláště u rizikových plemen psů.

Acknowledgement

The study was supported by ESF - project OP VK (CZ.1.07/2.3.00/09.0193).

\section{References}

Aronson LR, Brockman DJ, Brown DC 2000: Gastrointestinal emergencies. Vet Clin North Am Sm Anim Pract 30: $555-579$

Burrows CF, Bright RM, Spencer CP 1985: Influence of dietary composition on gastric emptying and motility in dogs: potential involvement in acute gastric dilatation. Am J Vet Res 46: 2609-2612

Crha M, Urbanová L, Lorenzova J, Svoboda T, Kala Z, Nečas A 2007: Současné možnosti laparoskopie u lidí a malých zvírat. Veterinářství 57: 733-737

Eggertsdottir AV, Moe L 1995: A retrospective study of conservative treatment of gastric dilatation-volvulus in the dog. Acta Vet Scand 36: 175-184

Elwood CW 1998: Risk factors for gastric dilatation for Irish setter dogs. J Small Anim Pract 39: 185-190

Fossum TW: Small Animal Surgery. St. Louis, Mosby, Elsevier, Third ed., 2007, 1610 p.

Funkquist B 1979: Gastric torsion in the dog. I. Radiological picture during nonsurgical treatment related to the pathological anatomy and to the further clinical course. J Small Anim Pract 20: 73-91

Glickman LT, Glickman NW, Perez CM 1994: Analysis of risk factors for gastric dilatation and dilatation-volvulus in dogs. J Am Vet Med Assoc 204: 1465-1471

Glickman LT, Emerick T, Glickman NW 1996: Radiological assessment of the relationship between thoracic conformation and the risk of gastric dilatation-volvulus in dogs. Vet Radiol Ultrasound 37: 174-180 
Glickman LT, Glickman NW, Schellenberg DB1997: Multiple risk factors for the gastric dilatation-volvulus syndrome in dogs: a practitioner/ owner case-control study. J Am Anim Hosp Assoc 33: 197-204

Glickman LT, Glickman NW, Schellenberg DB 2000a: Incidence of and breed-related risk factors for gastric dilatation-volvulus in dogs. J Am Vet Med Assoc 216: 40-45

Glickman LT, Glickman NW, Schellenberg DB 2000b: Non-dietary risk factors for gastric dilatation-volvulus in large and giant breed dogs. J Am Vet Med Assoc: 217: 1492-1499

Glickman LT, Lantz GC, Schellenberg DB, Glickman NW 1998: A prospective study of survival and recurrence following the acute gastric dilatation- volvulus syndrome in 136 dogs. J Am AnimHosp Assoc 34: 253-259

Greenfield CL, Walshaw R, Thomas MW 1989: Significance of the Heineke-Mikulicz pyloroplasty in the treatment of gastric dilatation-volvulus. A prospective clinical study. Vet Surg 18: 22-26

Hall JA 1989: Canine gastric dilatation-volvulus update. Semin Vet Med Surg 4: 188-193

Hall JA, Twedt DC, Curtis CR 1989: Relationship of plasma gastrin immunoreactivity and gastroesophageal sphincter pressure in clinically normal dogs and in dogs with previous gastric dilatation-volvulus. Am J Vet Res 50: 1228-1232

Hardie RJ, Flanders JA, Schmidt P, Credille KM, Pedrick TP, Short CE 1996: Biomechanical and histological evaluation of a laparoscopic stapled gastropexy technique in dogs. Vet Surg 25: 127-133

Kronfeld D 1979: Common questions about the nutrition of dogs and cats. Compend Contin Educ Pract Vet 1: $33-42$

Van Kruiningen HJ, Gregoire K, Meuten DJ 1974: Acute gastric dilatation: a review of comparative aspects, by species, and a study in dogs and monkeys. J Am Anim Hosp Assoc 10: 294-324

McCarthy TC: Veterinary Endoscopy for the Small Animal Practitioner. St. Louis, Elsevier, 1. ed., 2005, 606 p.

Millis DL, Nemzek J, Riggs C 1995: Gastric dilatation-volvulus after splenic torsion in two dogs. J Am Vet Med Assoc 207: 314-315

Monnet 2003: Gastric dilatation- volvulus syndrome in dogs. Vet Clin Small Anim 33: 987-1005

Morgan RV1982: Acute gastric dilatation-volvulus syndrome. Compend Contin Educ Pract Vet 4: 677-682

Rawlings CA 2002: Laparoscopic-assisted gastropexy. J Am Anim Hosp Assoc 38: 15-19

Rothuizen J 1985: Laparoscopy in small animal medicine. Vet Q 3: 225-228

Schaible RH, Ziech J, Glickman NW 1997: Predisposition to gastric dilatation-volvulus in relation to genetics of thoracic conformation in Irish Setters. J Am Anim Hosp Assoc 33: 379-383

Theyse LF, van de Brom WE, van Sluijs FJ 1998: Small size of food particles and age as risk factors for gastric dilatation volvulus in Great Danes. Vet Rec 143: 48-50

Thompson SE, Freeman LJ, Gallagher LA 1992: Laparoscopic stapled incisional gastropexy. Proceedings 27th Annual ACVS Meeting, Miami, Florida, USA 1992, p 28

Wilson ER, Henderson RA, Montgomery RD, Kincaid SA, Wright JC, Hanson RR 1996: A comparison of laparoscopic and belt-loop gastropexy in dogs. Vet Surg 25: 221-227

Wingfield WE, Betts CW, Greene RW 1975: Operative techniques and recurrence rates associated with gastric volvulus in the dog. J Small Anim Pract 16: 427-432 
Plate IV

Urbanová L. et al.: Clinical results ... pp. 93-99

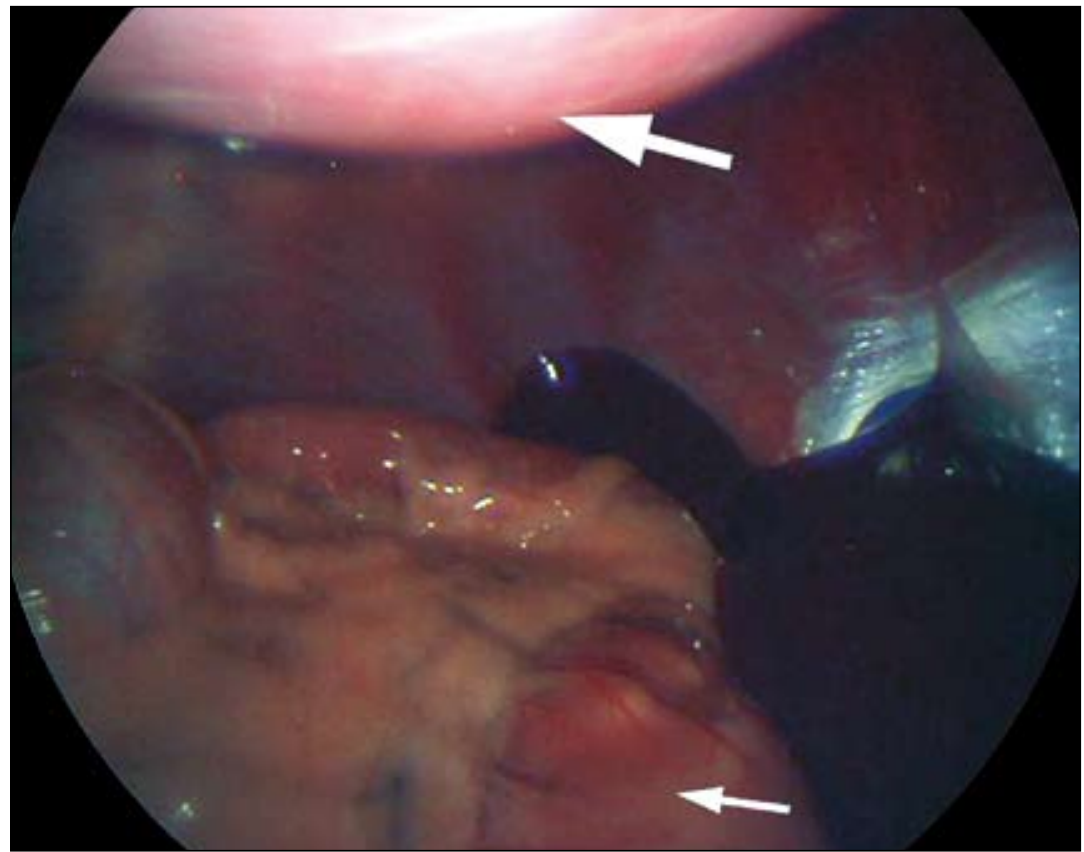

Fig. 1. Laparoscopic view of the right cranial quadrant of the abdominal cavity. Abdominal wall - area of future gastropexy (big arrow), prepyloric part of the stomach (small arrow).

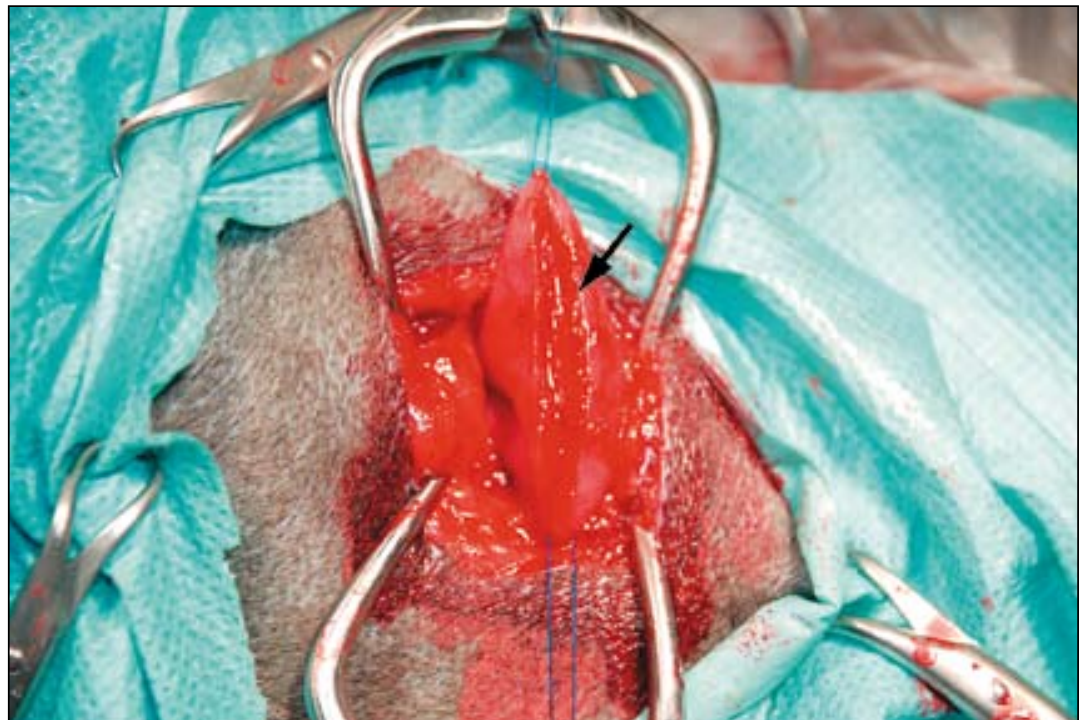

Fig. 2. View of the gastric wall with the seromuscular flap (arrow) after its extraction from the abdominal cavity through the small incision at the place of working port. 
Plate V

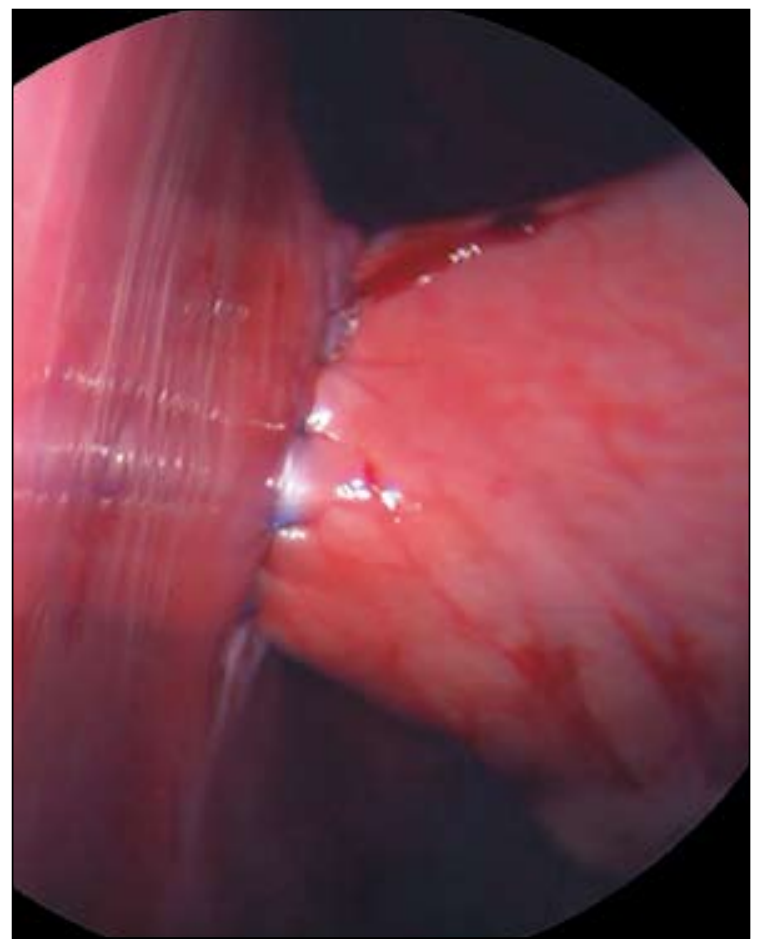

Fig. 3. Laparoscopic revision of the suture after finishing incisional gastropexy.

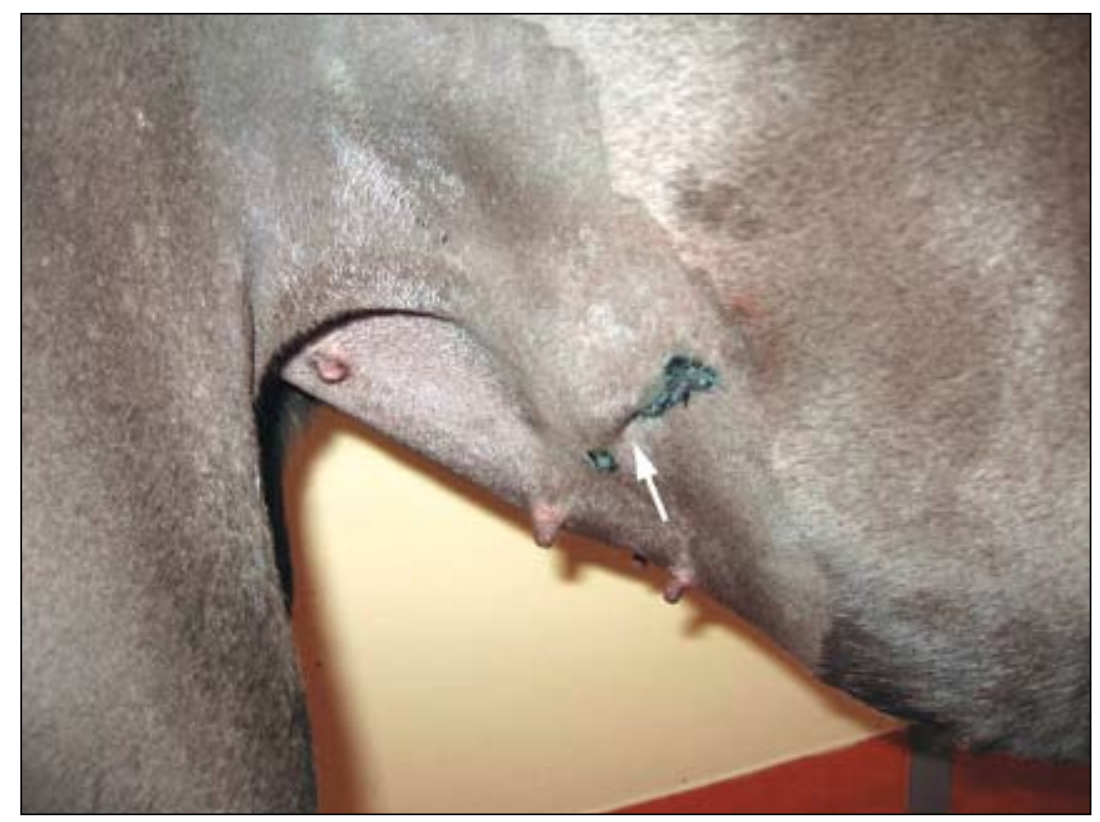

Fig. 4. Skinfold - crest (arrow) at the place of gastropexy immediately after surgery. 


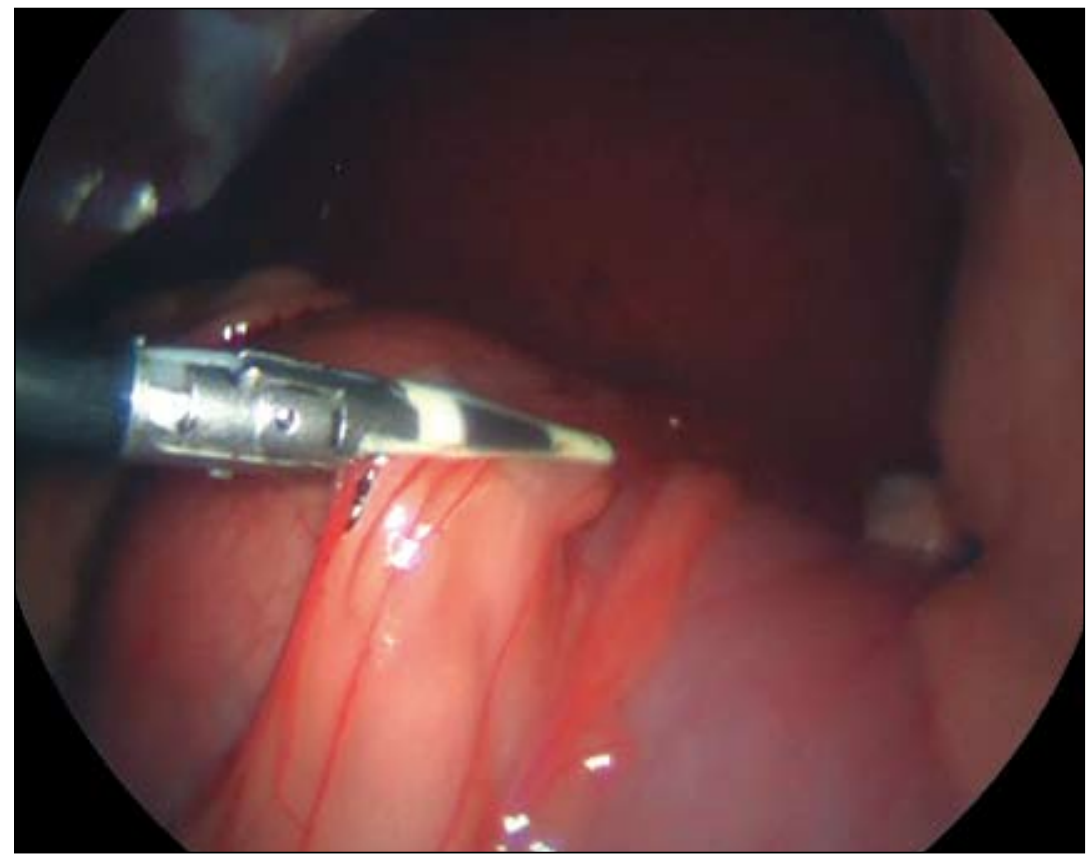

Fig. 5. Interruption of the ligament strip extending across the body of the stomach toward porta hepatis using the LigaSure ${ }^{\circledR}$.

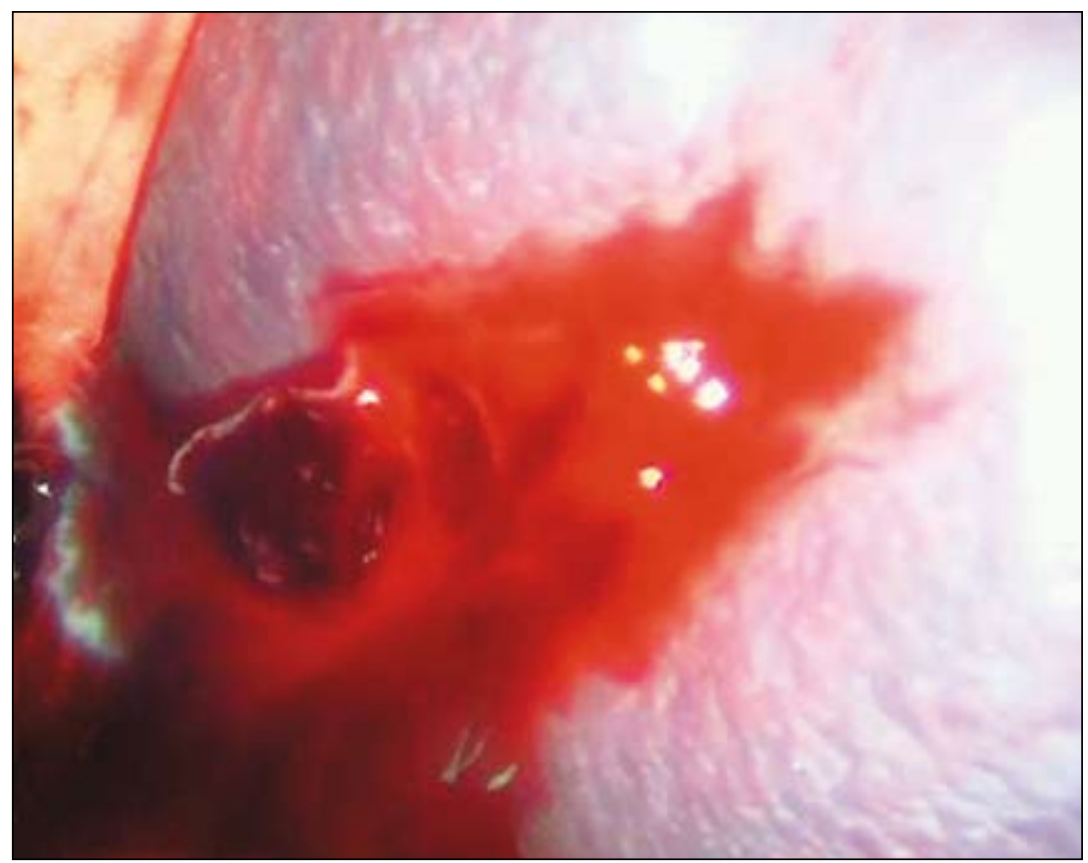

Fig. 6. Haemorrhage from the spleen after iatrogenic perforation of its capsule by the trocar when establishing the optical port. 